\title{
Influence of Brushing Time on Food Dynamics and Commercial Traits of Bombyx mori L. in Sub-tropical Plains of Jammu Region
}

\author{
Mokshe Sajgotra $^{{ }^{*}}$ and R. K. Bali \\ ${ }^{1}$ Dept. of Sericulture, Government Degree College, Udhampur, Jammu \& Kashmir (182 101), India \\ ${ }^{2}$ Division of Sericulture, Faculty of Agriculture, Sher-e-Kashmir University of Agricultural Sciences and Technology of Jammu, \\ Udheywalla, Jammu \& Kashmir (180 018), India
}

\author{
Corresponding Author \\ Mokshe Sajgotra \\ e-mail:mokshesajgotra@gmail.com
}

\author{
Article History \\ Article ID: AR1815g \\ Received in 01 ${ }^{\text {st }}$ June, 2017 \\ Received in revised form $28^{\text {th }}$ July, 2017 \\ Accepted in $5^{\text {th }}$ August, 2017
}

\begin{abstract}
In the present investigation, an attempt was made to study the effect of brushing time, silkworm hybrids and mulberry varieties for food dynamics and commercial trait expression. The experiment was laid out in factorial-completely randomized block design with eight treatments and three replications and the analysis of treatments was worked out by analysis of variance technique. The treatments comprised of two brushing time (early i.e. $1^{\text {st }}$ of March and late i.e. $20^{\text {th }}$ of March), two hybrids $\left(\mathrm{PO}_{3} \times \mathrm{ND}_{5}\right.$ and $\mathrm{SH}_{6} \times \mathrm{NB}_{4} \mathrm{D}_{2}$ ) and two mulberry varieties (China white and Tr-10). The brushing time, silkworm hybrids and mulberry varieties influenced significantly most of the food dynamic and cocoon traits. Observations made for food dynamics and commercially important traits indicated that, food ingestion and digestion, conversion of ingested and digested food, approximate digestibility, production efficiency of cocoon shell, efficiency of cocoon production, percentage of cocoon shell weight, effective rate of rearing (by weight and by number), single cocoon weight, single shell weight, shell ratio percentage, fibroin and sericin content, total filament length, non-breakable filament length and renditta were significantly higher for early brushing time, $\mathrm{PO}_{3} \times \mathrm{ND}_{5}$ and China white. Thus, only one commercial rearing is possible with brushing time of early i.e. $1^{\text {st }}$ of March for hybrid $\mathrm{PO}_{3} \times \mathrm{ND}_{5}$ fed on China white mulberry variety for spring rearing in the field at farmer's level for better prospects of bivoltine sericulture in sub-tropical plains.
\end{abstract}

Keywords: Brushing time, Bombyx mori, mulberry, food dynamics, commercial traits

\section{Introduction}

Silkworm, Bombyx mori L. is an important economic insect, feeding exclusively on the mulberry leaves (Morus spp.). Mulberry leaf quality is one of the key factors influencing the growth and development of silkworm, as the insect derives all the nutrients from mulberry leaf itself (Kumari and Roy, 2011). The production of quality cocoon crop is directly correlated with mulberry leaf and it contributes about $38.20 \%$ towards successful rearing/quality cocoon production, besides environmental conditions which contributes about 37.00\% (Bothikar et al., 2014; Ganie et al., 2012). Better the quality of mulberry leaves greater are the possibilities of obtaining good cocoon crops. Since the production of good quality cocoons depends on providing good quality leaves to silkworm, the development of superior quality leaf has become one of the prime objectives in mulberry breeding programme. Appropriate selection of the cultivars based on the plant morphology, disease resistance, biochemical properties and their effect on growth and cocoon yield parameters of Bombyx mori races/hybrids in different agroclimatic conditions is essential to select and exploit promising cultivars for better sericulture practices (Gaviria et al., 2006). However, a significant variation occurs in the nutritional value and composition of mulberry leaves depending upon the season, environmental conditions, agronomic practices, age of leaf etc. This variation impacts both qualitatively and quantitatively on the cocoon production (Chavadi et al., 2006; Gawade and Medhe, 2010). Under such conditions, the suitable mulberry variety needs to be developed for specific seasons and tested against the silkworm rearing for its quality in the form of worm growth, development and silk production as silkworm itself is the best evaluator of mulberry (Kumari et al., 2011). Varieties having higher yield containing better nutritional elements are always desirable to feed silkworm (Ramesha et al., 2012). It is a confirmed fact that leaf quality differs among mulberry varieties in different seasons which are responsible for the difference in rearing performance of the silkworm. Silkworm breeds/ hybrids differ in their nutritional requirements depending 
on the variety, rearing environment, season and quantum of nutrition (Sadaphal et al., 2015; Sutar et al., 2014). Thus, an experiment was conducted to study the effect of rearing time, silkworm hybrids and mulberry varieties on food dynamics and commercial trait expression of bivoltine silkworm hybrids in sub-tropical plains of Jammu region.

\section{Materials and Methods}

The present study was carried out during 2013-14 and 2014-15 at Division of Sericulture, Sher-e-Kashmir University of Agricultural Sciences and Technology, Udheywalla, Jammu, India to study the effect of brushing time, silkworm hybrids and mulberry varieties for food dynamics and commercial traits of Bombyx mori L. in sub-tropical plains of Jammu region during spring season. The experimental research material for the proposed study comprised of two brushing time for early spring ( $1^{\text {st }}$ of March) and late spring season (20 $0^{\text {th }}$ of March). Two bivoltine silkworm hybrids, $\mathrm{PO}_{3} \times \mathrm{ND}_{5}$ (evolved at Division of Sericulture, SKUAST-J, Udheywalla) and popular hybrid $\mathrm{SH}_{6} \times \mathrm{NB}_{4} \mathrm{D}_{2}$ were taken for the study. Two mulberry varieties (China white and Tr-10) leaves were used as food for rearing of worms. The experiment was laid out in Factorial-Completely Randomized Block Design (F-CRBD) with three replications each. All normal cultural practices like pruning, irrigation and fertilizer applications were followed as per the recommended package of practices for rainfed mulberry varieties (Dandin et al., 2010).

\subsection{Food dynamics}

The feed utilization/dynamic study was confined to IV and $\mathrm{V}$ instar larvae because around $80-85 \%$ of the total leaf is consumed in these two stages only. After resumption from third moult, 200 larvae each in three replications were separately reared. A reserve batch of 200 larvae was reared to compensate the missing larvae. Weighed quantities of fresh quality mulberry leaves were feed to silkworms three times a day at $10 \mathrm{am}, 4 \mathrm{pm}$ and $10 \mathrm{pm}$ respectively. Healthy larvae were counted daily in each replication of every treatment and under sized; unhealthy and dead larvae were removed and replaced from reserve batch maintained separately. From the bioenergetics data, nutritional parameters like ingestion, digestion, conversion of ingested food (ECI), conversion of digested food (ECD), approximate digestibility (AD), production efficiency of cocoon shell (PECS), efficiency of cocoon production (ECP) and percentage of cocoon shell weight (PCSW) were studied as suggested by Waldbauer, 1968 and Sarkar and Fujita, 1994.

\subsection{Commercial traits}

Silkworm seed of two hybrid combinations $\left(\mathrm{PO}_{3} \times \mathrm{ND}_{5}\right.$ and $\mathrm{SH}_{6} \times \mathrm{NB}_{4} \mathrm{D}_{2}$ ), was released from cold storage after completion of chilling treatment of 90 days. Standard rearing techniques as suggested by Dandin et al. (2003) were followed with slight modification of natural environmental conditions during the study (Table 1). After brushing, the silkworms were reared on two mulberry varieties viz., China white and $\operatorname{Tr}-10$ separately.

Table 1: Monthly meteorological parameters during the crop seasons

\begin{tabular}{|c|c|c|c|c|c|c|c|c|c|c|c|}
\hline \multirow{3}{*}{$\begin{array}{l}\text { Met. } \\
\text { Week }\end{array}$} & \multirow{3}{*}{$\begin{array}{l}\text { Date } \\
\& \\
\text { Month }\end{array}$} & \multicolumn{5}{|c|}{ 2013-2014 } & \multicolumn{5}{|c|}{ 2014-2015 } \\
\hline & & \multicolumn{2}{|c|}{ Temperature $\left({ }^{\circ} \mathrm{C}\right)$} & \multicolumn{2}{|c|}{ Relative humidity (\%) } & \multirow{2}{*}{$\begin{array}{l}\text { Rain- } \\
\text { fall } \\
(\mathrm{mm})\end{array}$} & \multicolumn{2}{|c|}{ Temperature $\left({ }^{\circ} \mathrm{C}\right)$} & \multicolumn{2}{|c|}{ Relative humidity (\%) } & \multirow{2}{*}{$\begin{array}{l}\text { Rain- } \\
\text { fall } \\
(\mathrm{mm})\end{array}$} \\
\hline & & Maximum & Minimum & Morning & Afternoon & & Morning & Minimum & Morning & Afternoon & \\
\hline 9 & $\begin{array}{l}\text { 26-4 } \\
\text { March }\end{array}$ & 19.5 & 9.7 & 88 & 64 & 116.6 & 23.3 & 8.3 & 86 & 58 & 35.8 \\
\hline 10 & $\begin{array}{l}\text { 5-11 } \\
\text { March }\end{array}$ & 20.6 & 9.7 & 91 & 63 & 20.8 & 27.8 & 10.9 & 78 & 53 & 0.0 \\
\hline 11 & $\begin{array}{l}12-18 \\
\text { March }\end{array}$ & 22.6 & 10.1 & 89 & 63 & 107.4 & 25.5 & 11.9 & 89 & 55 & 5.7 \\
\hline 12 & $\begin{array}{l}\text { 19-25 } \\
\text { March }\end{array}$ & 29.1 & 13.5 & 83 & 47 & 0 & 27.7 & 13.1 & 80 & 47 & 35.7 \\
\hline 13 & $\begin{array}{l}\text { 26-1 } \\
\text { April }\end{array}$ & 26.1 & 15.5 & 85 & 67 & 99.6 & 28.4 & 12.6 & 89 & 49 & 0.0 \\
\hline 14 & $\begin{array}{l}2-8 \\
\text { April }\end{array}$ & 25.0 & 15.1 & 83 & 58 & 112.0 & 30.1 & 13.2 & 83 & 32 & 0.0 \\
\hline 15 & $\begin{array}{l}\text { 9-15 } \\
\text { April }\end{array}$ & 31.4 & 16.8 & 74 & 46 & 0 & 32.8 & 14.7 & 79 & 32 & 2.2 \\
\hline 16 & $\begin{array}{l}16-22 \\
\text { April }\end{array}$ & 32.1 & 17.8 & 77 & 48 & 30 & 32.8 & 16.1 & 72 & 30 & 1.2 \\
\hline 17 & $\begin{array}{l}23-29 \\
\text { April }\end{array}$ & 35.1 & 19.2 & 63 & 63 & 0 & 33.5 & 16.3 & 68 & 30 & 1.2 \\
\hline
\end{tabular}


Three replications were maintained for each treatment. Each replication had a population of 200 larvae. Ripe worms were picked for seriposition and spinning was conducted on collapsible plastic mountages. The cocoons were harvested on sixth day during spring season after mounting. Data was recorded replication-wise for all commercial traits viz., effective rate of rearing (ERR) (by weight and by number), single cocoon weight, single shell weight, shell ratio percentage, fibroin and sericin content, total filament length, non-breakable filament length, denier and renditta.

\subsection{Statistical analysis}

To estimate significant differences among brushing time, silkworm hybrids and mulberry variety; the mean data of each character were subjected to Analysis of Variance techniques (ANOVA). The results were tested for the treatments mean by applying F- test of significance on the basis of null hypothesis as mentioned by Cochran and Cox (1957).

\section{Results and Discussion}

\subsection{Food dynamics}

Highlighting the importance of ingesta and digesta, Horie et al. (1995) reported that for the production of $1 \mathrm{~g}$ larval weight requirement of ingesta and digesta is $4.2 \mathrm{mg}$ and $1.8 \mathrm{mg}$ respectively. Food intake (ingestion) by silkworm is an indicator of its preference for a particular varietal leaf. In the present study, brushing time, hybrids and varieties exhibited significant differences among themselves for IV \& V instar (Table 2). The results revealed significant effect of early brushing time over mean value of late brushing rearing $(556.62 \mathrm{~g}, 2509.31 \mathrm{~g})$ than early season rearing (546.54 g, 2397.36) for both IV \& V instar. The effects of hybrids show that $\mathrm{PO}_{3} \times \mathrm{ND}_{5}$ with $556.42 \mathrm{~g}$ and $2569.66 \mathrm{~g}$ was significantly superior to $\mathrm{SH}_{6} \times \mathrm{NB}_{4} \mathrm{D}_{2}(546.75 \mathrm{~g}, 2337.01 \mathrm{~g})$ during IV \& V instar in spring crop. Mulberry varieties also exhibited significant effect for this parameter. Variety $\operatorname{Tr}-10$ with 561.37 $\mathrm{g}$ and $2532.82 \mathrm{~g}$ realized significant increase in ingestion during IV \& V instar over China white with $541.79 \mathrm{~g}$ and $2373.85 \mathrm{~g}$ only. The leaf ingestion was higher during late stage rearing with most of it being consumed during $V$ instar. The present findings are in conformity to those of Koul et al. (1994) who reported that leaf consumption increased during $V$ instar from first to eighth day and it varied according to the mulberry variety, due to varied biochemical composition. Further, Kumari et al. (2011) reported higher ingesta in $V$ instar necessary for larval metabolism during the transformation of larva to pupa, pupa to moth and also for secretion of silk. Digesta (digestion), which is the quantity of food assimilated, indicates the amount of nutrients passed through the digestive system for utilization. Digestion mainly is governed by the physiology of the worm, its nutritional value and requirement. The amount of digesta for IV instar was

Table 2: Effect of different treatments on food dynamics (two years mean data)

\begin{tabular}{|c|c|c|c|c|c|c|c|c|c|c|c|c|c|}
\hline \multirow[t]{2}{*}{ Treatments } & \multicolumn{2}{|c|}{$\begin{array}{l}\text { Food ingestion } \\
\text { (g) }\end{array}$} & \multicolumn{2}{|c|}{ Digestion (g) } & \multicolumn{2}{|c|}{$\begin{array}{l}\text { Conversion } \\
\text { of ingested } \\
\text { food (ECl) }\end{array}$} & \multicolumn{2}{|c|}{$\begin{array}{c}\text { Conversion of } \\
\text { digested food } \\
\text { (ECD) }\end{array}$} & \multicolumn{2}{|c|}{$\begin{array}{l}\text { Approximate } \\
\text { digestibility } \\
\text { (AD) }\end{array}$} & \multirow[t]{2}{*}{ PECS } & \multirow[t]{2}{*}{ ECP } & \multirow[t]{2}{*}{ PCSW } \\
\hline & IV & V & IV & V & IV & V & IV & V & IV & V & & & \\
\hline \multicolumn{14}{|l|}{ Brushing time } \\
\hline Early (1 $1^{\text {st }}$ of Mar.) & 546.54 & 2397.36 & 412.24 & 1188.22 & 25.37 & 34.19 & 33.53 & 69.21 & 75.51 & 49.62 & 3.17 & 0.32 & 20.12 \\
\hline Late $\left(20^{\text {th }}\right.$ of Mar.) & 556.62 & 2509.31 & 457.63 & 1479.85 & 22.24 & 32.03 & 27.22 & 57.34 & 81.97 & 58.25 & 3.00 & 0.26 & 20.45 \\
\hline SEm \pm & 2.59 & 10.74 & 3.02 & 13.71 & 0.39 & 0.38 & 0.55 & 1.06 & 0.29 & 0.45 & 0.03 & 0.004 & 0.16 \\
\hline $\operatorname{LSD}(p=0.05)$ & 7.78 & 32.19 & 9.06 & 41.12 & 1.19 & 1.14 & 1.66 & 3.17 & 0.86 & 1.37 & 0.10 & 0.01 & NS \\
\hline \multicolumn{14}{|l|}{ Hybrids } \\
\hline $\mathrm{PO}_{3} \times \mathrm{ND}_{5}$ & 556.42 & 2569.66 & 436.79 & 1371.15 & 24.14 & 31.44 & 30.98 & 61.20 & 78.37 & 52.99 & 3.26 & 0.29 & 22.22 \\
\hline $\mathrm{SH}_{6} \times \mathrm{NB}_{4} \mathrm{D}_{2}$ & 546.75 & 2337.01 & 433.07 & 1296.92 & 23.47 & 34.78 & 29.76 & 65.34 & 79.11 & 54.87 & 2.91 & 0.30 & 18.34 \\
\hline SEm \pm & 2.59 & 10.74 & 3.02 & 13.71 & 0.39 & 0.38 & 0.55 & 1.06 & 0.29 & 0.45 & 0.03 & 0.004 & 0.16 \\
\hline $\operatorname{LSD}(p=0.05)$ & 7.78 & 32.19 & NS & 41.12 & NS & 1.14 & NS & 3.17 & NS & 1.37 & 0.10 & 0.01 & 0.49 \\
\hline \multicolumn{14}{|l|}{ Variety } \\
\hline China white & 541.79 & 2373.85 & 424.90 & 1338.68 & 23.10 & 33.79 & 29.66 & 62.11 & 78.29 & 55.93 & 3.24 & 0.29 & 20.64 \\
\hline Tr-10 & 561.37 & 2532.82 & 444.96 & 1329.39 & 24.51 & 32.43 & 31.08 & 64.43 & 79.19 & 51.94 & 2.93 & 0.29 & 19.92 \\
\hline SEm \pm & 2.59 & 10.74 & 3.02 & 13.71 & 0.39 & 0.38 & 0.55 & 1.06 & 0.29 & 0.45 & 0.03 & 0.004 & 0.16 \\
\hline $\operatorname{LSD}(p=0.05)$ & 7.78 & 32.19 & 9.06 & NS & 1.19 & 1.14 & NS & NS & 0.86 & 1.37 & 0.10 & NS & 0.49 \\
\hline
\end{tabular}

PECS: Production efficiency of cocoon shell (PECS); ECP: Efficiency of cocoon production (ECP); PCSW: Percentage of cocoon shell weight (PCSW) 
significant for both brushing time and varieties during spring (Table 2). For brushing time, late brushing rearing recorded highest and significant results of $457.63 \mathrm{~g}$ than early season rearing which recorded $412.24 \mathrm{~g}$ value. Among mulberry varieties, significant differences with increasing trend in variety $\mathrm{Tr}-10$ at $444.96 \mathrm{~g}$ was observed in comparison to China white with $424.90 \mathrm{~g}$. In the present investigation, digestion exhibited significant differences during $\mathrm{V}$ instar for brushing time and hybrids (Table 2). Late brushing time recorded maximum digestion of $1479.85 \mathrm{~g}$ followed by early brushing time $(1188.22 \mathrm{~g})$. Among hybrids, $\mathrm{PO}_{3} \times \mathrm{ND}_{5}$ recorded significantly more digestion during $\mathrm{V}$ age (1371.15 g) than $\mathrm{SH}_{6} \times \mathrm{NB}_{4} \mathrm{D}_{2}$ (1296.92 g). The rate of digestion decreased during later stages of fifth instar which is attributed to reduced metabolic activities, coinciding with increased silk synthesis in silk glands. According to Prabhakara et al. (2000), the rate of digestion in silkworm differed when fed on different varieties of mulberry, which falls in line with the present observations. The conversion of ingested food $(\mathrm{ECI})$ is an overall measure of ability to utilize the consumed food after digestion for growth. $\mathrm{ECl}$ mainly depends on approximate digestibility which on one hand is converted into body substance and on the other gets metabolized for energy to maintain life. The nutritional efficiency of conversion is considered an important physiological criterion for evaluating the superiority of silkworm breeds/hybrids. In the present study, $\mathrm{ECl}$ was found to be significant for brushing time and varieties only for IV instar, whereas, brushing time, hybrids and varieties exhibited significant differences among the treatments studied for $\mathrm{V}$ instar (Table 2 ). The results reveal significant effect of brushing time and mean value of early brushing rearing (25.37) was higher than late brushing rearing (22.24) during IV instar. Being significant, the higher $\mathrm{ECI}$ (24.51) for IV age was registered with Tr-10 mulberry variety in comparison to China white variety (23.10). Among brushing time, early brushing time expressed positive and significant increase to the extent of 34.19, whereas late brushing time recorded 32.03 values only for $\mathrm{V}$ instar. In case of hybrids for $\mathrm{V}$ instar, $\mathrm{SH}_{6} \times \mathrm{NB}_{4} \mathrm{D}_{2}$ recorded higher $\mathrm{ECl}$ of 34.78 and was found to be significantly higher than hybrid $\mathrm{PO}_{3} \times \mathrm{ND}_{5}$ which recorded a value of 31.44 only. Significant higher value of 33.79 was registered with China white and $\mathrm{Tr}-10$ remained at 32.43 for $\mathrm{V}$ instar. The variation in $\mathrm{ECl}$ may be due to varied rate of metabolism which is governed by the nutritional value of the food. Similar differences were observed Kumari et al., (2012). Conversion of digested food (ECD) explains the ability of worm to utilize the portion of food that is digested for growth and development. The ECD measures the efficiency of conversion of assimilated food and the $\mathrm{ECl}$ measures the overall efficiency of conversion of ingested food into worm biomass. During spring, brushing time expressed significant results for IV instar and brushing time and hybrids observed significant differences for $V$ instar. Among brushing time, early brushing rearing had significantly higher ECD for IV age (33.53) than the late brushing rearing (27.22). For $V$ instar, early brushing time had significantly higher ECD (69.21) than late brushing time (57.34) and the hybrid $\mathrm{SH}_{6} \times \mathrm{NB}_{4} \mathrm{D}_{2}$ registered highest ECD of 65.34 for $\mathrm{V}$ age while as $\mathrm{PO}_{3} \times \mathrm{ND}_{5}$ recorded 61.20 only. Similar difference was observed with respect to ECD by Ramesha et al. (2012) who reported that ECD decreased with larval growth. Approximate digestibility (AD) is a precise measure of digestibility to evaluate the food compared to the amount of food digested. It measures the digestible portion of the food that is ingested. In the present study, AD expressed significant differences for brushing time and varieties for IV age, whereas $\mathrm{V}$ age recorded significant differences for all treatments viz., brushing time, hybrids and varieties (Table 2). Late brushing time had significantly higher approximate digestibility (81.97) than early brushing time (75.51) for IV instar. Higher and significant approximate digestibility was registered with $\mathrm{Tr}-10$ variety (79.19) over China white (78.29) for IV instar. Late brushing time recorded maximum approximate digestibility $(58.25)$ followed by early brushing time (49.62) during $\mathrm{V}$ instar. Among the hybrids, $\mathrm{SH}_{6} \times \mathrm{NB}_{4} \mathrm{D}_{2}$ recorded significantly more approximate digestibility for $\mathrm{V}$ age (54.87) than $\mathrm{PO}_{3} \times \mathrm{ND}_{5}$ (52.99). Significant effect of mulberry variety China white (55.93) over Tr-10 (51.94) was recorded for approximate digestibility for $V$ age. This variation may be due to the nutritional differences of mulberry varieties utilized as food and also due to moisture content in leaves and excreta. The approximate digestibility analyzed in the study indicates that higher food intake does not necessarily result in higher digestibility. The higher values of $A D$ indicate greater suitability of mulberry leaves and environmental conditions provided to silkworms. Since the digestibility differs in different treatments, the proportion of food intake and production of fecal matter also varies (Ramesha et al., 2012). The findings validate the results that revealed a highly significant variation on nutritional traits between the hybrids during different brushing time as reported by Ramesha et al. (2012). Kumari et al. (2011) suggested that approximate digestibility and efficiency of conversion of ingested food to body substance (ECI) were inversely correlated with larval age. Ramesha et al. (2012) has suggested that food utilization differs in IV and $\mathrm{V}$ instar for $A D, E C l, E C D, C l$ and $G R$ and accordingly leaf inputs needs to be regulated for desirable effects on cocoon characters. The nutritional efficiency of food ingested by silkworms is usually evaluated in terms of the proportion of cocoon shell weight to the amount of food ingested, i.e., production efficiency of cocoon shell (PECS). The production efficiency of cocoon shell is generally used to identify the superiority of a mulberry variety for silkworm rearing. The usefulness of the parameter has been studied and the mulberry varieties with high PECS are generally rated as high quality varieties. The present study on PECS reveals statistically significant results with respect to brushing time, hybrids and varieties in spring cocoon crop (Table 2). Early brushing time recorded significantly higher 
value of 3.17 for PECS than late brushing time which recorded lower PECS value of 3.00. In case of hybrids, $\mathrm{PO}_{3} \times \mathrm{ND}_{5}$ recorded higher PECS value of 3.26 and was found to be significantly higher than hybrid $\mathrm{SH}_{6} \times \mathrm{NB}_{4} \mathrm{D}_{2}$ with the value of 2.91 only. Variety China white recorded a significantly higher value of 3.24 while as variety $\mathrm{Tr}-10$ recorded 2.93 for PECS. However, the efficiency of cocoon production (ECP) was significantly different for brushing time and hybrids only (Table 2). Early brushing time with value 0.32 was found to be significantly superior to late brushing time for ECP of 0.26 . $\mathrm{SH}_{6} \times N_{4} \mathrm{D}_{2}$ recorded significant increase in $\mathrm{ECP}$ with corresponding value of 0.30 over $\mathrm{PO}_{3} \times \mathrm{ND}_{5}(0.29)$ during spring season. Percentage of cocoon shell weight (PCSW) exhibited significant differences for hybrids and varieties (Table 2). The data pertaining to percentage of cocoon shell weight reveals that hybrid $\mathrm{PO}_{3} \times \mathrm{ND}_{5}$ (22.22) was significantly higher than hybrid $\mathrm{SH}_{6} \times \mathrm{NB}_{4} \mathrm{D}_{2}$ (18.34). Being significant, the higher percentage of cocoon shell weight was registered with China white (20.64) over Tr-10 mulberry variety (19.92). PECS showed high and significant correlation with ECP and PCSW and significantly negative correlation with amount of food ingested and digested. Mulberry varieties possessing high PECS have better convertibility and intake of leaves of such varieties as food by silkworm is low. Sarkar and Fujita (1994) concluded that high PECS may be treated as the final indicator for evaluation of nutritive value of mulberry leaves. The results of the present study are in close conformity with those reported by Jalaja and Nair (2011).

\subsection{Commercial traits}

Sajgotra et al. (2016) suggested that effective rate of rearing (by weight and by number), good cocoon percentage, pupation percentage, single cocoon weight, shell weight and shell ratio percentage are important parameter for quality cocoon crop. From different treatments studied, only brushing time was found to be significant for effective rate of rearing (by weight) while as, hybrids and varieties did not have any significant difference for this parameter (Table 3). For brushing time, early brushing time recorded higher and significant results of $19.02 \mathrm{~kg}$ than late season rearing of $15.63 \mathrm{~kg}$. This may be due to congenial temperature and relative humidity conditions prevailing during study period. The findings are in close conformity to that of Kumar et al. (2013). ERR by number being an important parameter contributes towards viability. Among different treatments studied, brushing time and hybrids were found to be significant for effective rate of rearing (by number). Mulberry varieties did not exhibit any significant difference for this parameter (Table 3). For brushing time, early brushing time recorded higher and significant results of 9542 than late brushing time (8900). Hybrid, $\mathrm{SH}_{6} \times \mathrm{NB}_{4} \mathrm{D}_{2}$ showed significant increase with corresponding value of 9392 over $\mathrm{PO}_{3} \times \mathrm{ND}_{5}$ (9050). Higher significant values for cocoon yield by number can be ascribed to the fact that cocoon yield by weight also exhibited significant differences for brushing time. The present results corroborates with the findings of Kumar et al. (2013). The cocoon weight, shell weight and shell ratio are the important commercial parameters for cocoon stage and

\begin{tabular}{|c|c|c|c|c|c|c|c|c|c|c|c|}
\hline \multirow[t]{2}{*}{ Treatments } & \multicolumn{2}{|c|}{$\begin{array}{c}\text { Effective rate of } \\
\text { rearing (ERR) }\end{array}$} & \multirow{2}{*}{$\begin{array}{c}\text { Single } \\
\text { cocoon } \\
\text { weight } \\
\text { (g) }\end{array}$} & \multirow{2}{*}{$\begin{array}{c}\text { Single } \\
\text { shell } \\
\text { weight } \\
\text { (g) }\end{array}$} & \multirow{2}{*}{$\begin{array}{c}\text { Shell } \\
\text { ratio per- } \\
\text { centage }\end{array}$} & \multirow{2}{*}{$\begin{array}{l}\text { Fibroin } \\
\text { con- } \\
\text { tent } \\
(\%)\end{array}$} & \multirow{2}{*}{$\begin{array}{c}\text { Sericin } \\
\text { con- } \\
\text { tent } \\
(\%)\end{array}$} & \multirow{2}{*}{$\begin{array}{c}\text { Total } \\
\text { filament } \\
\text { length } \\
(\mathrm{m}) \\
\end{array}$} & \multirow{2}{*}{$\begin{array}{c}\text { Non- } \\
\text { breakable } \\
\text { filament } \\
\text { length }(\mathrm{m})\end{array}$} & \multirow{2}{*}{$\begin{array}{c}\text { De- } \\
\text { nier } \\
\text { (d) }\end{array}$} & \multirow[t]{2}{*}{$\begin{array}{l}\text { Ren- } \\
\text { ditta }\end{array}$} \\
\hline & $\begin{array}{c}\text { By wt. } \\
\text { (kg) }\end{array}$ & By no. & & & & & & & & & \\
\hline \multicolumn{12}{|l|}{ Brushing time } \\
\hline Early (1 $1^{\text {st }}$ of Mar.) & 19.02 & 9542 & 1.90 & 0.38 & 20.12 & 71.92 & 27.62 & 870.33 & 864.02 & 2.61 & 7.26 \\
\hline Late (20 of Mar.) & 15.63 & 8900 & 1.82 & 0.37 & 20.45 & 72.62 & 27.24 & 858.75 & 850.66 & 2.78 & 7.06 \\
\hline SEm \pm & 0.24 & 99.30 & 0.02 & 0.004 & 0.16 & 0.19 & 0.29 & 14.39 & 14.25 & 0.04 & 0.09 \\
\hline $\operatorname{LSD}(p=0.05)$ & 0.72 & 297.75 & 0.05 & NS & NS & 0.58 & NS & NS & NS & 0.13 & NS \\
\hline \multicolumn{12}{|l|}{ Hybrids } \\
\hline $\mathrm{PO}_{3} \times \mathrm{ND}_{5}$ & 17.03 & 9050 & 1.88 & 0.41 & 22.22 & 75.02 & 24.54 & 967.37 & 959.83 & 2.71 & 6.08 \\
\hline $\mathrm{SH}_{6} \times \mathrm{NB}_{4} \mathrm{D}_{2}$ & 17.62 & 9392 & 1.85 & 0.34 & 18.34 & 69.52 & 30.31 & 761.70 & 754.87 & 2.68 & 8.24 \\
\hline SEm \pm & 0.24 & 99.30 & 0.02 & 0.004 & 0.16 & 0.19 & 0.29 & 14.39 & 14.25 & 0.04 & 0.09 \\
\hline $\operatorname{LSD}(p=0.05)$ & NS & 297.75 & NS & 0.01 & 0.49 & 0.58 & 0.87 & 43.15 & 42.74 & NS & 0.29 \\
\hline \multicolumn{12}{|l|}{ Variety } \\
\hline China white & 17.49 & 9175 & 1.87 & 0.38 & 20.64 & 72.65 & 27.34 & 872.45 & 864.91 & 2.72 & 6.90 \\
\hline Tr-10 & 17.16 & 9267 & 1.86 & 0.37 & 19.92 & 71.89 & 27.52 & 856.62 & 849.79 & 2.67 & 7.42 \\
\hline SEm \pm & 0.24 & 99.30 & 0.02 & 0.004 & 0.16 & 0.19 & 0.29 & 14.39 & 14.25 & 0.04 & 0.09 \\
\hline $\operatorname{LSD}(p=0.05)$ & NS & NS & NS & 0.01 & 0.49 & 0.58 & NS & NS & NS & NS & 0.29 \\
\hline
\end{tabular}


reeling performance. Cocoon weight and shell weight are the most important characters evaluated for productivity (Gaviria et al., 2006). Cocoon weight has a negative correlation with shell ratio but positive correlation with shell weight, whereas shell weight has a positive correlation with shell ratio. Data presented in Table 3 represents significant difference for different brushing time only. Early brushing time exhibited significant increase in single cocoon weight (1.90) over late brushing time (1.82). This indicates the superiority of hybrids in different brushing time and is in support of the view that phenomenon of heterosis could be either due to additive gene action or due to dominance hypothesis. Shell weight content is a quality parameter for evaluation of mulberry and has a positive co-relation with cocoon shell ratio. Shell weight in the present study, exhibited significant superiority for hybrids and varieties (Table 3). $\mathrm{PO}_{3} \times \mathrm{ND}_{5}$ resulted in significant increase with corresponding value of $0.41 \mathrm{~g}$ over $\mathrm{SH}_{6} \times \mathrm{NB}_{4} \mathrm{D}_{2}(0.34 \mathrm{~g})$. Among the cultivars, China white (0.38) proved significantly superior to $\operatorname{Tr}-10$ (0.37). This indicates that varieties studied are having potential for economic exploitation. Similar trend with respect to shell weight was observed by Maqbool et al. (2005). Shell ratio percentage indicates the amount of raw silk reeled from given quantity of fresh cocoons and shell percentage varies according to silkworm breed/hybrids. Shell ratio percentage was found to be significant for both hybrid and varieties and data presented in Table 3 shows that brushing time did not have any significant difference. Hybrid, $\mathrm{PO}_{3} \times \mathrm{ND}_{5}$ was significantly higher at 22.22 than hybrid $\mathrm{SH}_{6} \times \mathrm{NB}_{4} \mathrm{D}_{2}$ (18.34). Among the cultivars, China white (20.64) proved to be significantly superior to $\operatorname{Tr}-10$ variety (19.92). This might be due to higher ingestion, digestion and conversion factors. These results corroborate with the findings of Sadaphal et al. (2015). Silk fiber is almost a pure protein composed of fibroin and sericin. Fibroin is the main body of the thread whereas sericin is a gummy substance meant for holding the fibroin intact in the form of cocoon. Different brushing time, hybrids and varieties had significant difference in terms of fibroin content, while as significant increase in sericin content was recorded for hybrids only (Table 3). Late brushing time resulted in significant increase in fibroin with corresponding value of 72.62 over early brushing time which recorded a value of 71.92. Among the hybrids, $\mathrm{PO}_{3} \times \mathrm{ND}_{5}$ recorded significantly higher fibroin content of 75.02 than $\mathrm{SH}_{6} \times \mathrm{NB}_{4} \mathrm{D}_{2}$ (69.52). Among varieties, China white produced significantly more fibroin (72.65) than Tr-10 (71.89). Ram et al. (1998) reported highly positive correlation between cocoon shell weight and fibroin. Hybrid $\mathrm{SH}_{6} \times \mathrm{NB}_{4} \mathrm{D}_{2}$ recorded significantly higher sericin content of 30.31 over $\mathrm{PO}_{3} \times \mathrm{ND}_{5}$ which remained at 24.54 only. Higher fibroin content could be due to higher shell ratio among the treatments studied. It is desirable to have less sericin content as higher sericin content indirectly effects the raw silk production and as such is not a desirable character from commercial and breeding point of view.
Post cocoon/reeling characters may not be of much importance to rearers but have greater significance not only from reeler's point of view but also from industrial view. Among post cocoon parameters, filament length and denier are considered as important characters from economic point of view and have direct bearing on the merit of a breed/ hybrid. Increase or decrease in filament length is dependent on increase or decrease in the thickness of silk filament and cocoon shell weight of breeds and hybrids. Results of the present study did not reveal any significant difference for brushing time and varieties for total filament length, however different hybrids showed significant increase for total filament length (Table 3). $\mathrm{PO}_{3} \times \mathrm{ND}_{5}$ recorded significantly higher filament length of $967.37 \mathrm{~m}$, whereas $\mathrm{SH}_{6} \times \mathrm{NB}_{4} \mathrm{D}_{2}$ recorded $761.70 \mathrm{~m}$ only. This finding can be attributed to longer $\mathrm{V}$ instar duration and higher larval weight (Satenahalli et al., 1990). Rajalakshmi et al. (2000) opines that the quality of a good hybrid is to have minimum or no breaks during the process of reeling. Different brushing time and varieties again did not reveal any significant difference in spring crop for non-breakable filament length. Hybrids were found to influence non-breakable filament length significantly (Table 3). Among the hybrids, $\mathrm{PO}_{3} \times \mathrm{ND}_{5}$ recorded significantly higher value of 959.83 , whereas $\mathrm{SH}_{6} \times \mathrm{NB}_{4} \mathrm{D}_{2}$ recorded 754.87 only. Similar were the findings of Kumar et al. (2013). Denier being genetically controlled trait and as such it may not have significant co-relation with other parameters. It represents the thinness or thickness of the filament and was found to be non-significant for hybrids and varieties during spring (Table 3). It differed significantly due to brushing time and was higher at 2.78 in late brushing than that of early brushing (2.61). The results are in accordance with the findings of (Satenahalli et al., 1990).

\section{Conclusion}

Postponing brushing time is liable to reduce commercial characters drastically due to higher temperature unsuitable for crop yield and qualitative traits. Hence, most suitable brushing time for the region is $1^{\text {st }}$ of March. Hybrid $\mathrm{PO}_{3} \times$ $\mathrm{ND}_{5}$ fed on China white mulberry variety responds well to the brushing time with respect to good crop production and hence can be utilized for spring rearing in the field at farmer's level for better prospects of bivoltine sericulture in sub-tropical plains.

\section{References}

Bothikar, P.A., Jadhav, S.S., Shinde, Y.A., 2014. Growth and development of silk worm (Bombyx mori L.) on mulberry leaves. Journal of Industrial Pollution Control 30(2), 239-241.

Chavadi, V.B., Aparna, H.S., Manjunatha, H.B., 2006. Impact of heat shock on heat shock proteins expression, biological and commercial traits of Bombyx mori. Insect Science 13, 243-250. 
Cochran, W.G., Cox, G.M., 1957. Experimental Designs. Wiley International Publication, New York.

Dandin, S.B., Jayant, J., Giridhar, K., 2003. Handbook of Sericulture Technologies. Central Silk Board, Bangalore.

Ganie, N.A., Kamili, A.S., Baqual, M.F., Sharma, R.K., Dar, K.A., Khan, I.L., 2012. Indian sericulture industry with particular reference to Jammu \& Kashmir. International Journal of Advanced Biological Research 2(2), 194-202.

Gaviria, D., Aguilar, H.J., Serrano, Alegria, A.H., 2006. DNA fingerprinting using AFLP markers to search for makers associated with yield attributes in the silkworm Bombyx mori. Journal of Insect Science 6, 1-10.

Gawade, B.V., Medhe, N.K., 2010. Feeding effect of some mulberry varieties on larval weight of $\mathrm{si}$ I $\mathrm{k} \mathrm{w}$ o $\mathrm{r} \mathrm{m}$, Bombyx mori L. Green Farming 1(5), 545-546.

Horie, Y., 1995. Recent advances of nutritional physiology and artificial diet of the silkworm in Japan. Korean Journal of Sericulture Science 37, 235-243.

Jalaja, S.K., Nair, S.K., 2011. Production efficiency of cocoon shell of silkworm, Bombyx mori L. (Bombycidae: Lepidoptera), as an index for evaluating the nutritive value of mulberry, morus spp. (moraceae), varieties. Psyche 1, 1-3.

Koul, A., Singh, D., Sharma, C.P., 1994. Palatability of some mulberry varieties to silkworm. Entomon 19(3), 115-117.

Kumar, H., Satya Priya, Y., Kumar, M., Elangovan, V., 2013. Effect of different mulberry varieties and seasons on growth and economic traits of bivoltine silkworm (Bombyx mori). Journal of Entomology 10(3), 147-155.

Kumari, N., Roy, S.P., 2011. Some aspects of the identification of nutritionally efficient silkworms (Insecta: lepidoptera: Bombycoidea), their metabolic rate and sustainable development as energy resources. The Bioscan 6(3), 475-481.

Kumari, S.S., Subba Rao, S.V., Misra, S., Murthy, U.S., 2011. Screening strains of the mulberry silkworm, Bombyx mori, for thermotolerance. Journal of Insect Science 11, 116-123.

Maqbool, A., Malik, G.N., Dar, H.V., Kamili, A.S., Gulzaffar. 2005. Evaluation of some bivoltine silkworm (Bombyx mori L.) genotype under different seasons. Indian Journal of Sericulture 4(2), 147-155.

Prabhakara, M.K., Reddy, D.N.R., Visweswara Gowda, B.L., Narayanaswamy, K.C. 1992. Leaf consumption pattern during fourth and fifth instars in Bombyx mori L. as influenced by mulberry varieties. Mysore Journal of Agriculture Sciences 26, 91-99.

Rajalakshmi, E., Chauhan, T.P.S., Kamble, S.B.T., Mahadevaiah, B.M. 2000. Evaluation of newly evolved bivoltine hybrids of Bombyx mori L. for silk yield contributing traits under hill conditions. Indian Journal of Sericulture 39(1), 21-23.

Ram, K., Singh, D., Koul, A., 1998. Correlation studies on cocoon shell and fibroin contents in silkworm (Bombyx mori L.). Journal of Sericulture 6(1\&2), 34-36.

Ramesha, C., Lakshmi, H., Kumari, S.S., Anuradha, C.M., Kumar, C.S., 2012. Nutrigenetic screening strains of the mulberry silkworm, Bombyx mori, for nutritional efficiency. Journal of Insect Science 12(3), 1-18.

Sadaphal, P.D., Latpate, C.B., Nikam, T.A., 2015. Performance of bivoltine silkworm hybrid on different mulberry cultivars under rainfed conditions. The Ecoscan 3, 173-176.

Sajgotra, M., Bali, R.K., 2016. Evaluation and identification of potential bivoltine silkworm hybrids of Bombyx mori $\mathrm{L}$. Indian Journal of Ecology 43(1), 396-399.

Sarkar, A., Fujita, H., 1994. Better technique for nutritive evaluation of mulberry leaves for silkworm, Bombyx mori L. Indian Journal of Sericulture 33(1), 19-22.

Satenahalli, S.B., Govindan, R., Goud, J.V., Magadum, S.B., 1990. Genetic parameters and correlation coefficient analysis in silkworm Bombyx mori L. Mysore Journal of Agriculture Sciences 24, 491-495.

Sutar, A.V., Khemnar, S.S., Gaikwad, B.B., Mudgalkar, A.B., 2014. Evaluation of different mulberry varieties against mulberry silkworm Bombyx mori L. for rearing performance and economic traits. Journal of Entomological Research 38(4), 251-254.

Waldbauer, G.P., 1968. The consumption and utilization of food by insects. Advances in Insect Physiology 5, 229-288. 